\title{
A combination of climate, tree diversity and local human disturbance determine the stability of dry Afromontane forests
}

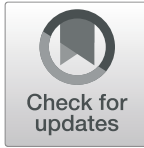

Hadgu Hishe ${ }^{1,2^{*}} \mathbb{D}$, Louis Oosterlynck ${ }^{1}$, Kidane Giday ${ }^{2}$, Wanda De Keersmaecker ${ }^{1,3}$, Ben Somers ${ }^{1}$ and Bart Muys ${ }^{1}$

\begin{abstract}
Background: Anthropogenic disturbances are increasingly affecting the vitality of tropical dry forests. The future condition of this important biome will depend on its capability to resist and recover from these disturbances. So far, the temporal stability of dryland forests is rarely studied, even though identifying the important factors associated with the stability of the dryland forests could serve as a basis for forest management and restoration.
\end{abstract}

Methodology: In a degraded dry Afromontane forest in northern Ethiopia, we explored remote sensing derived indicators of forest stability, using MODIS satellite derived NDVI time series from 2001 to 2018. Resilience and resistance were measured using the anomalies (remainders) after time series decomposition into seasonality, trend and remainder components. Growth stability was calculated using the integral of the undecomposed NDVI data. These NDVI derived stability indicators were then related to environmental factors of climate, topography, soil, tree species diversity, and local human disturbance, obtained from a systematic grid of field inventory plots, using boosted regression trees in $\mathrm{R}$.

Results: Resilience and resistance were adequately predicted by these factors with an $R^{2}$ of 0.67 and 0.48 , respectively, but the model for growth stability was weaker. Precipitation of the wettest month, distance from settlements and slope were the most important factors associated with resilience, explaining $51 \%$ of the effect. Altitude, temperature seasonality and humus accumulation were the significant factors associated with the resistance of the forest, explaining $61 \%$ of the overall effect. A positive effect of tree diversity on resilience was also important, except that the impact of species evenness declined above a threshold value of 0.70 , indicating that perfect evenness reduced the resilience of the forest. Precipitation of the wettest month was the most important factor explaining $43.52 \%$ of the growth stability variation.

Conclusion: A combination of climate, topographic factors and local human disturbance controlled the stability of the dry forest. Also tree diversity is an important stability component that should be considered in the management and restoration programs of such degraded forests. If local disturbances are alleviated the recovery time of dryland forests could be shortened, which is vital to maintain the ecosystem services these forests provide to local communities and global climate change.

Keywords: Climate, Dryland, Disturbance, Restoration, Tigray, Growth stability, Biodiversity function

\footnotetext{
* Correspondence: hishadi@gmail.com

${ }^{1} \mathrm{KU}$ Leuven, Department of Earth and Environmental Sciences, Division

Forest, Nature and Landscape, Celestijnenlaan 200E, P.O. Box 2411, 3001

Leuven, Belgium

${ }^{2}$ Department of Land Resource Management and Environmental Protection,

Mekelle University, College of Dryland Agriculture and Natural Resources, P.O.

Box 231, Mekelle, Tigray, Ethiopia

Full list of author information is available at the end of the article
}

\section{Springer Open}

(c) The Author(s). 2021 Open Access This article is licensed under a Creative Commons Attribution 4.0 International License, which permits use, sharing, adaptation, distribution and reproduction in any medium or format, as long as you give appropriate credit to the original author(s) and the source, provide a link to the Creative Commons licence, and indicate if changes were made. The images or other third party material in this article are included in the article's Creative Commons licence, unless indicated otherwise in a credit line to the material. If material is not included in the article's Creative Commons licence and your intended use is not permitted by statutory regulation or exceeds the permitted use, you will need to obtain permission directly from the copyright holder. To view a copy of this licence, visit http://creativecommons.org/licenses/by/4.0/. 


\section{Introduction}

A significant area of the globe (41\%) is covered with drylands, and a large part of the human population (35\%) resides in them (Safriel and Adeel 2008). Among dryland ecosystems, the dry forest biome covers an estimated 1079 million ha (Bastin et al. 2017), accounting for almost half of the (sub) tropical forests (Aide et al. 2013). Dryland forests are very important for biodiversity conservation, as they are known for their high level of endemism (Myers et al. 2000); also for deep aquifer recharge as they show high infiltration rates in a lacking water environment (Bargués-Tobella et al. 2020), and for moderating high temperatures. Dryland forests are some of the most threatened by human degradation and therefore, maintaining the remnant forests is crucial for a sustainable environment, and a seed source for possible restoration (Safriel et al. 2005; Díaz et al. 2018).

Dry forests are among the most threatened ecosystems (Bognounou et al. 2010) as they are found in regions of low productivity, supporting population with one of the fastest birth rates, where poverty prevails (Safriel and Adeel 2008). Dry forests have high conversion rates to other land use, and the remaining parts are degraded and fragmented (Sánchez-Azofeifa et al. 2005).

Due to climate change and other anthropogenic causes, desertification is widespread in drylands and is impacting the overall well-being of dwellers (Yan et al. 2011). Climate change-induced prolonged dryness could change the vegetation composition of dryland forests, which might further complicate the socioeconomic situation in these areas (Huang et al. 2016). Local disturbance factors such as illegal logging, uncontrolled browsing and grazing, and fire incidences are adding on to, and are possibly interfering with, the effect of global climate change on dryland forests (Lloret et al. 2007; Jacob et al. 2014; Abrha and Adhana 2019; Hishe et al. 2020). Understanding how forests respond to increasing climate change and local human pressure is crucial to keep a sustained flow of the ecosystem services, ecosystem stability (Jactel et al. 2006; Bauhus et al. 2017; Duffy et al. 2017) and should be an essential component of forest management (Huang et al. 2016). This is important as not all forests respond in the same way to global and local disturbances. Their responses are modulated by local landscape characteristics such as species composition, altitude, slope and edaphic factors. Diverse versus monoculture stands, for example, are reported to respond differently to disturbance (Johnson et al. 1996; Van Ruijven and Berendse 2007; De Keersmaecker et al. 2018). While a number of studies reported that tree diversity has a positive effect on production, health and stability of forests, other have reported either neutral or negative effect of diversity which indicates for a need of further study (Waide et al. 1999; McCann 2000). As a consequence restoration planning protocols will need context specific information.

Different metrics have been proposed to define and quantify the responses of forests to disturbances (Webb 2007; Yan et al. 2011). Among these, growth stability, resilience and resistance have been used widely (Verbesselt et al. 2016; De Keersmaecker et al. 2018). Many definitions are given to the mentioned stability concepts (Nikinmaa et al. 2020). The resilience is defined as the recovery rate after a disturbance (Dakos et al. 2012). Resistance, on the other hand, is the capacity of the forest to remain unchanged regardless of disturbances (Grimm and Wissel 1997). Growth stability is considered as a steady continuity of growth irrespective of external disturbance (Chen et al. 2019).

Ecosystem stability is affected by different factors, such as climate, topography and species diversity, among others (Yan et al. 2011; Hutchison et al. 2018). Insight in the response of the ecosystem to change in these factors is valuable for management and restoration purposes. In the absence of long-term ecological experiments, remote sensing data analysis is providing an opportunity to monitor long term forest dynamics (Wang et al. 2004). Typically, vegetation indices based on the ratio between the reflectance in red and near-infrared (NIR) bands, such as the Normalized Different Vegetation Index (NDVI) (Kogan 1995), are used to characterize vegetation properties (Lu et al. 2016). NDVI time series thus provide valuable information on forest dynamics and their response to external pressures (Lhermitte et al. 2011; Verbesselt et al. 2016; De Keersmaecker et al. 2018).

Forest stability metrics can be derived by applying statistical analysis to the entire NDVI time series, holistic approach, to take the possible recurrent stochastic perturbation events such as drought and other environmental variations in an open environment into consideration (Verbesselt et al. 2016; Hutchison et al. 2018). Within the holistic approach, temporal autocorrelation (TAC) (Verbesselt et al. 2016), the depth of the anomalies (De Keersmaecker et al. 2014) and the standard deviation of the anomalies (Pimm 1984) from a decomposed time series are commonly used as an indicator of forest resilience and resistance, respectively. TAC is based on the assumption that forests with lower resilience will recover more slowly, and growth progress is dependent on previous performances (Verbesselt et al. 2016). Hence, higher TAC values indicate a slow forest response to these perturbations, showing lower recovery rate of the system. $\mathrm{TAC}$ is thus a measure of the slowness of forest response after disturbances and a direct indicator of resilience (Verbesselt et al. 2016). TAC can be used to assess how close a system is close to a critical transition point (CTP) to another stable system, the higher the 
autocorrelation (close to one) the closer the system is to the CTP (Leemput et al. 2018). Subtracting the TAC from one, on the other hand, indicates how close a system is to its prior disturbance state (the recovery rate in its broad sense), which could be considered as the resilience of the system (Verbesselt et al. 2016).

Similarly, as resistance is defined as the ability to withstand external shocks where highly resistant forests will deviate less than forests with low resistance during perturbations, the depth of the deviation is considered as an indicator of resistance (De Keersmaecker et al. 2014). In addition, growth stability can be measured by calculating the area under the curve of the undecomposed NDVI at a yearly basis and is measured by the inverse of the coefficient of variation (mean divided by the standard deviation) of the respective years of the time series (Isbell et al. 2009).

Apart from quantifying the degree of stability of forests to disturbances, understanding and predicting the effect of environmental factors strengthening or weakening forest stability is little explored (Yan et al. 2011). Therefore, this research aims at quantifying the effect of different explanatory variables describing tree species diversity, local degradation indicators and climate on forest resilience, resistance and growth stability over time using MODIS NDVI time series. Such information will be crucial for planning a successful restoration and forest management (Anjos and De Toledo 2018). With this respect, the study strives to test the following hypotheses: 1) precipitation and temperature play a vital role in the stability of dry forests, 2) topographic and edaphic factors and local land degradation indicators further modulate the difference in the stability of forests, 3) stands with multispecies composition have more growth stability resistance and resilience under climate fluctuation and human disturbances than monocultures.

\section{Methods}

\section{Study area description}

The study was carried out in Desa'a Forest, a large degraded dry Afromontane forest situated in the Tigray and Afar regions in the north of Ethiopia, for which an ambitious restoration plan is ongoing. The altitudes range from $900 \mathrm{~m}$ in Afar lowlands to $3000 \mathrm{~m}$ in the highlands of Tigray (Fig. 1). Due to the large difference in topography and long north-south extension along the escarpment, the geologic formation of the forest area is diverse (Asrat 2002). The bedrock in Desa'a Forest is mainly made up of a Precambrian basement in the northern part and the Hintalo limestone dotted with Adigrat Sandstone in the southern landscape (Williams 2016).

The precipitation pattern of the study area is influenced by topography and rain-bearing winds and is dominated by a large inter-annual variability (Nyssen et al. 2005). Data from a nearby meteo-station and Worldclim (http://worldclim.org/version2) (Fick and Hijmans 2017) indicate that the average annual temperature and precipitation of the study area ranges between $13{ }^{\circ} \mathrm{C}$ to $25^{\circ} \mathrm{C}$ and 400 to $700 \mathrm{~mm}$ respectively. Drought has a long history in the area, and caused

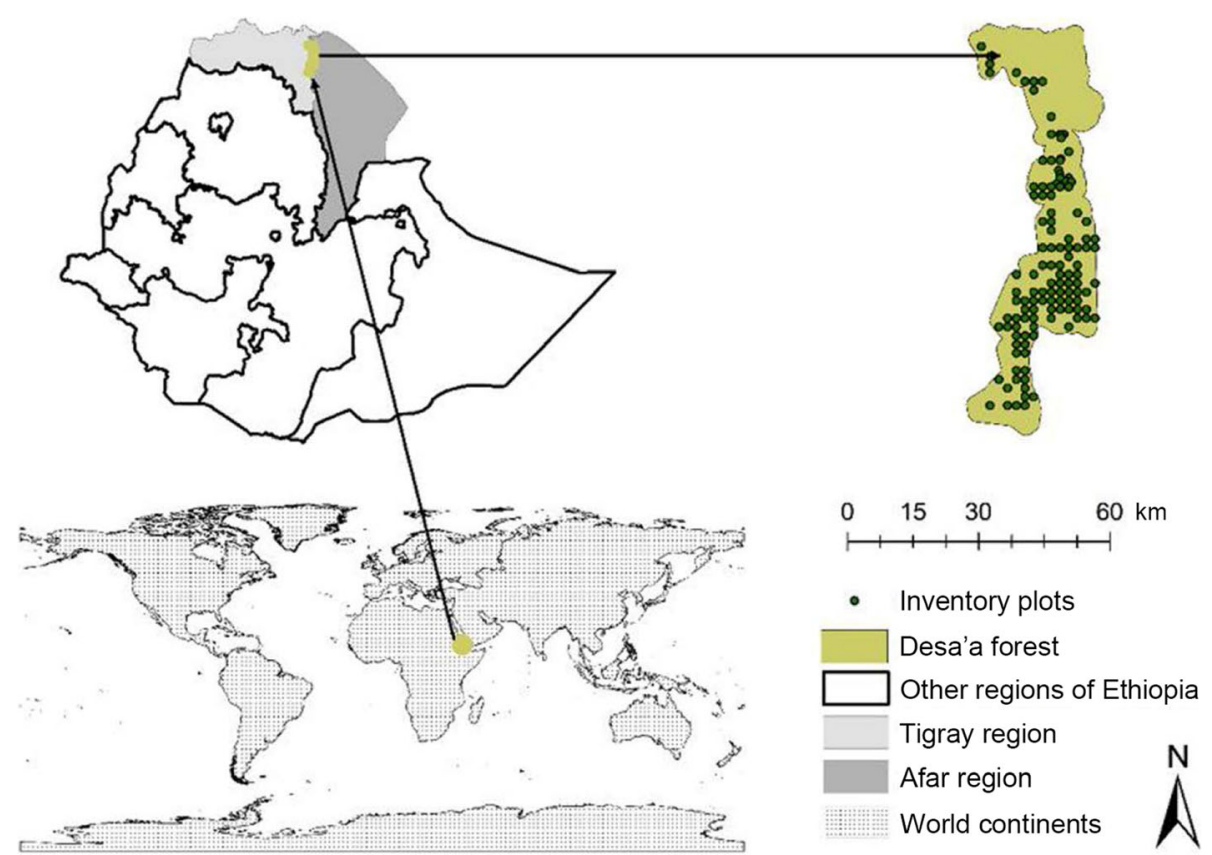

Fig. 1 Location of Desa'a Forest in Ethiopia, and the position of the sampling points 
regular famines, including in recent times. Recent droughts have been recorded for 2000, 2002, 2004 and 2009 (Gebrehiwot and van der Veen 2013). In a recent study, 2012 and 2013 were added among the driest years in the region (Tefera et al. 2019).

Desa'a Forest is most often classified as a dry Afromontane forest with a long dry season, where Juniperus procera Hochst. ex Endl. and Olea europaea subsp. cuspidata (Wall. ex G. Don) Cif. are the dominant species (Friis et al. 2010) in the canopy and understory, respectively. In Aynekulu et al. (2012), dry Afromontane forest (JuniperOlea-Tarchonanthus group), semi-deciduous shrubland (Cadia-Acacia group), open acacia woodland and semidesert shrubland (Balanites group) was identified from top to bottom along the altitude gradient. The forest is under strong degradation pressure by livestock and overcutting and is undergoing fast species composition change (Aynekulu et al. 2011)) with a $500 \mathrm{~m}$ upward shift in the tree line for juniper and olive species so far (Aynekulu et al. 2011). Desa'a forest covers an area of 150,000 ha.

\section{Data collection \\ Environmental factors}

The ground data were collected by systematic sampling, based on a $2 \mathrm{~km}$ by $2 \mathrm{~km}$ grid. At each corner of the grids, 303 plots of $400 \mathrm{~m}^{2}$ were established on which all woody species, shrubs and trees, were identified following the nomenclature of Ethiopian flora (Tesemma 2007) and counted. For each tree, diameter at breast height $(\mathrm{DBH})$ at $1.3 \mathrm{~m}$ above ground was measured using a calliper. For shrubs, diameter at stump height $(\mathrm{DSH})$ at $30 \mathrm{~cm}$ above ground was measured. Trees with at least $5 \mathrm{~cm}$ in $\mathrm{DBH}$ and shrubs with at least $1 \mathrm{~cm}$ in DSH were considered. Only plots with a vegetation cover above $10 \%$ following the FAO definition of forest, 131 plots were used (FAO 2010). For the shrub and tree layers, canopy cover was estimated by a group of three experts and an average was recorded.

For each plot, slope, aspect and altitude were extracted from the $30 \mathrm{~m}$ spatial resolution ASTER Digital Elevation Model. The 19 standard Bioclimatic variables for 30 years (1970-2000) were extracted at $1 \mathrm{~km}$ resolution from the WorldClim WebPortal (http://worldclim.org/version2) (Fick and Hijmans 2017). The definition and nature of the bioclimatic variables are well documented in Fick and Hijmans (2017) and (O’Donnell and Ignizio 2012).

Distance to nearby settlements and roads were extracted from a Euclidean distance raster constructed from a digitized road and settlement shapefiles. The shapefiles were obtained from a combination of data digitized from Google earth, and GPS tracked major and feeder roads, towns and centre of encompassing villages.

In every plot, local disturbance indicators such as fire incidence, grazing and logging severity were estimated (see appendix 1, supplementary material) following Aynekulu et al. (2011). In each of the diversity inventory plots, soil depth was measured by penetrating a metal rod until the bedrock is reached. The thickness of the forest floor (ectorganic humus layer) was measured after cutting a profile with a spade (Eriksson and Holmgren 1996) (Table 1).

\section{Satellite imagery}

Moderate Resolution Imaging Spectroradiometer (MODIS) satellite data, i.e. the global MOD13Q1 data product with a temporal resolution of 16 days and a spatial resolution of $250 \mathrm{~m}$, was used. MODIS NDVI time series from 2001 to 2018 were downloaded from Google Earth Engine (Hird et al. 2017). Upon downloading, low data quality observations such as pixels covered by clouds were masked (Hird et al. 2017). NDVI values were extracted for the pixels covering each inventory plot for every scene as a matrix of bimonthly NDVI over the 18 years in R-software.

\section{Data analysis \\ Time series decomposition}

The time series were decomposed into trend, seasonality and remainder (anomalies) components using SeasonalTrend decomposition using Loess (STL) (Abbes et al. 2018) in R software. The trend component indicates long-term forest development, while the seasonal component depicts annual growth variations (Quan et al. 2016). The remainder is the difference obtained when the trend and seasonality are subtracted from the original time series (Verbesselt et al. 2016) (Fig. 2).

\section{Deriving ecosystem stability metrics from the NDVI time series}

Three stability metrics were used to describe forest dynamics: resilience, resistance, and growth stability. While resilience and resistance were based on the anomalies of the NDVI time series (De Keersmaecker et al. 2014),

Table 1 Categorical environmental factors collected in the field (Lower rank indicates better forest condition and higher values indicate bad forest condition; while soil depth, humus depth and erosion status were assessed into five ranks, grazing, cutting and fire incidence were ranked into four)

\begin{tabular}{llllll}
\hline Factors & \multicolumn{2}{l}{ Ranks } & & \\
\cline { 2 - 6 } & $\mathbf{1}$ & $\mathbf{2}$ & $\mathbf{3}$ & $\mathbf{4}$ & $\mathbf{5}$ \\
\hline Soil Depth $(\mathrm{cm})$ & $>100$ & $75-100$ & $50-75$ & $25-50$ & $0-25$ \\
Humus Depth $(\mathrm{cm})$ & $>10$ & $5-10$ & $2-5$ & $0-2$ & 0 \\
Erosion & Absent & Low & Moderate & high & Very high \\
Grazing & Absent & Low & Medium & High & - \\
Cutting & Absent & Low & Medium & High & - \\
Fire incidence & Absent & Low & Medium & High & - \\
\hline
\end{tabular}




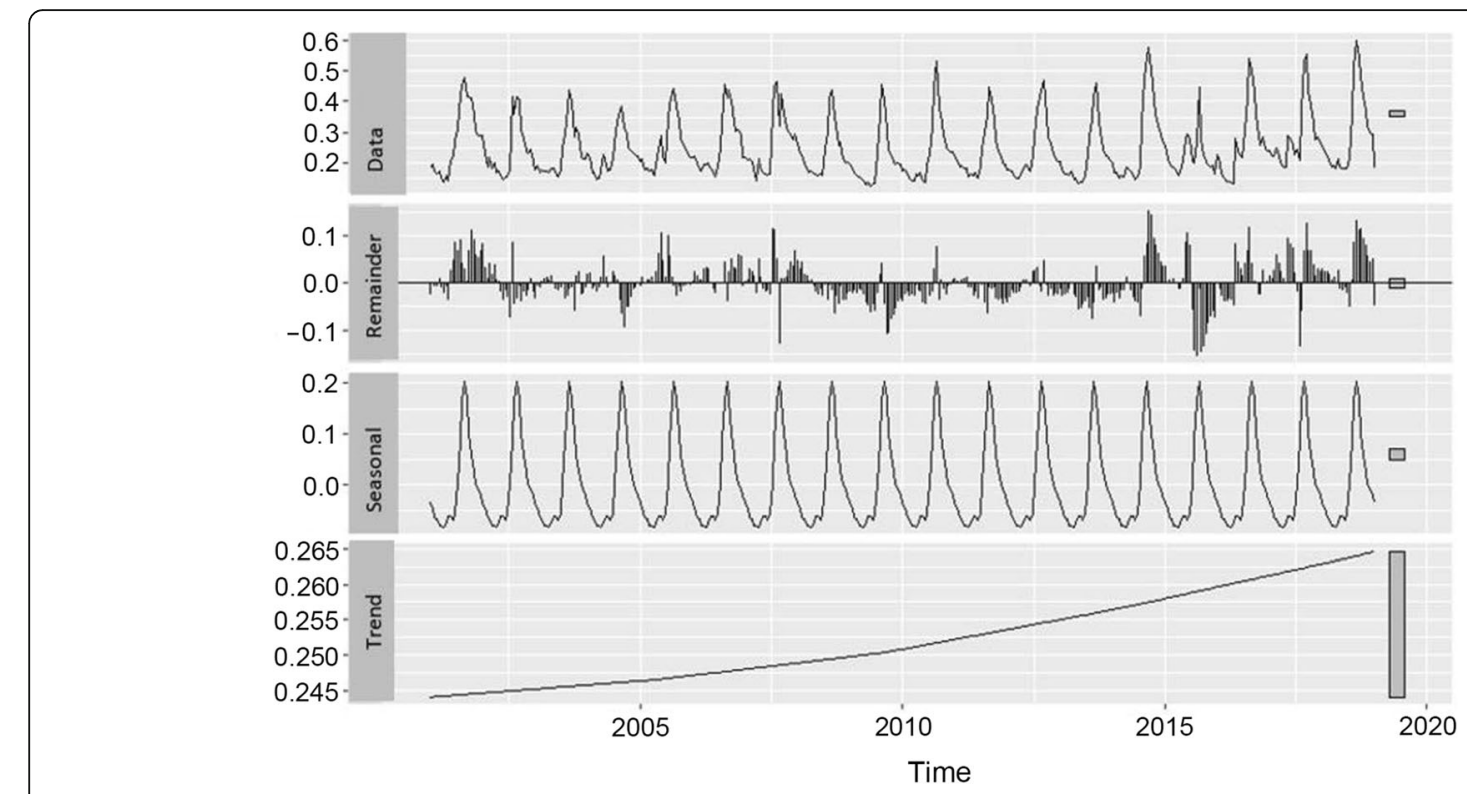

Fig. 2 An example of an NDVI time series of Desa'a forest, study area, decomposed using the STL algorithm

growth stability was based on the integrals of the undecomposed NDVI time series (Isbell et al. 2009).

Resilience Resilience (Fig. 3) was computed using the temporal auto-correlation (TAC) of the anomaly. TAC and resilience are given in the following formula (Dakos et al. 2012), Eqs. 1 and 2, respectively. Highly correlated events $(=$ high $\mathrm{TAC})$ represent a slow recovery rate $(=$ low resilience).

$$
\mathrm{TAC}=\frac{\sum_{t=i}^{n-1}\left(X_{t}-\bar{X}\right)\left(X_{t+1}-\bar{X}\right)}{\sum_{t=1}^{n}\left(X_{t}-\bar{X}\right)^{2}}
$$

$$
\text { Resilience }=1-\mathrm{TAC}
$$

where TAC is the temporal autocorrelation at lag $1, X_{t}$ stands for the observation at time $t$ and $n$ equals the total number of observations.
Resistance The resistance was calculated as the lowest 5 th percentile of the remainder (anomalies) per year (De Keersmaecker et al. 2014) (Fig. 3). Small values for the resistance metric represent highly resistant forests, i.e. forests that will deviate to a small extent during perturbations.

Growth stability The growth stability was calculated from the integral of the undecomposed NDVI time series (Yin et al. 2012). The area under the curve of yearly based NDVI time series was considered as a good proxy for the net primary production (growth) of the forest. This area under the curve was obtained based on the top $75 \%$ of the yearly NDVI response to avoid the possible effect of seasonal variation in vegetation properties such as leaf sheds (Fig. 4). The growth stability was then calculated as the inverse of the coefficient of variation (i.e. a ratio of mean to standard deviation) of the area under the curve.

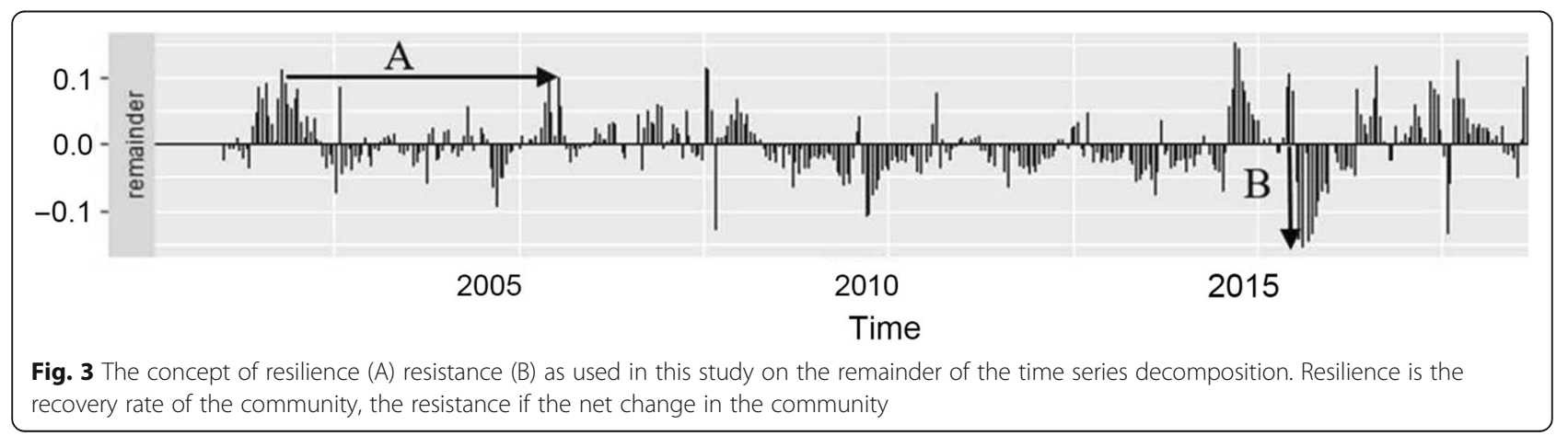




\section{Tree diversity}

Basal area (BA) based on species diversity was derived using the Shannon-Wiener diversity index $\left(H^{\prime}\right)$ and evenness index $(J)$ equations (Shannon 1948), Eqs. 3 and 4 , respectively.

$$
\begin{aligned}
& H^{\prime}=\sum_{s=0}^{s} \mathrm{BA}_{i} \ln \left(\mathrm{BA}_{i}\right)^{\prime} \\
& J=\frac{H^{\prime}}{H^{\prime} \max }=\sum_{s=0}^{s} \mathrm{BA}_{i} \ln \left(\mathrm{BA}_{i} / \ln (s)\right)
\end{aligned}
$$

where $H^{\prime}$ is the Shannon-Wiener diversity index, $J$ is Shannon-Wiener evenness index, and $\mathrm{BA}_{i}$ is the BA proportion $(n / N)$ of individuals of the abundance of the $i^{\text {th }}$ species (one particular species) found $(n)$ divided by the total number of individuals found $(N)$ (species richness), and $S$ is the number of species. These diversity indices were later used as explanatory variables in the regression analysis.

\section{Statistical analyses}

The four forest stability metrics were modeled against climate, tree species diversity, edaphic and topographic variables and land degradation indicators. Boosted Regression Trees (BRT) was applied as a regression model (Elith et al. 2008) for each metric to explain the dynamics of the forest as a system and identify the most important factors predicting each metric.

BRT allows handling of complex interactions while allowing simplicity for ecological interpretation (Elith et al. 2008; Aertsen et al. 2012). BRT combines the power of regression trees and boosting. It continuously partitions the data into homogeneous parts and fits a specific model to each partition. This avoids the loss of unexplained data if a single regression model could be fitted into such complex interactions. In R-environment, BRT was run using the gbm.step function developed by
Elith et al. (2008) which as an extension of the "gbm" package (Ridgeway 2007), and explanatory variables could be simplified to concentrate on the most meaningful and important ones using the gbm.simplify to boost the power of the model (Elith et al. 2008).

The different variables used in the analyses were checked for multi-collinearity using the variation inflation factor (VIF) and Pearson correlation. Variables with higher VIF $(>5)$ and Pearson correlation $(>0.7)$ between predictors were not included in the reported outputs (Aertsen et al. 2012). BRT was run for the different stability metrics by varying the learning rates $(0.001-0.05)$, tree complexity $(1-5)$ and bag fraction $(0.50-0.75)$. Model performance was measured using R-squared, AIC and root mean square error (RMSE). In the BRT, the cross-validation (CV) statistic is the most important measure to evaluate the results (Elith et al. 2008). The cross-validation correlation is the mean correlation of the predicted data iteratively based on the number of folds (Elith et al. 2008). The higher the correlation, the higher the predictive power of the model. Because the algorithm is of a stochastic nature, based on the bag fraction used (the default is $75 \%$ ), a portion of the data (here $50 \%$ was used) is used to train the model and the remaining for prediction capability test. Variable importance is determined by averaging the number of times, a variable is selected in the iterative division (splitting) of data weighted by the squared improvement to the BRT model (Gu et al. 2019). Variables that are above the median of the group in the model value are highly important (significant), and those that are below are less important variables in the model (Gu et al. 2019). Results were also supported by partial dependence plots to ease ecological interpretability of the effect trend of the factors considered.

To generate wall to a wall map of stability metrics over the forest, a kriging interpolation in ArcMap10.6 was

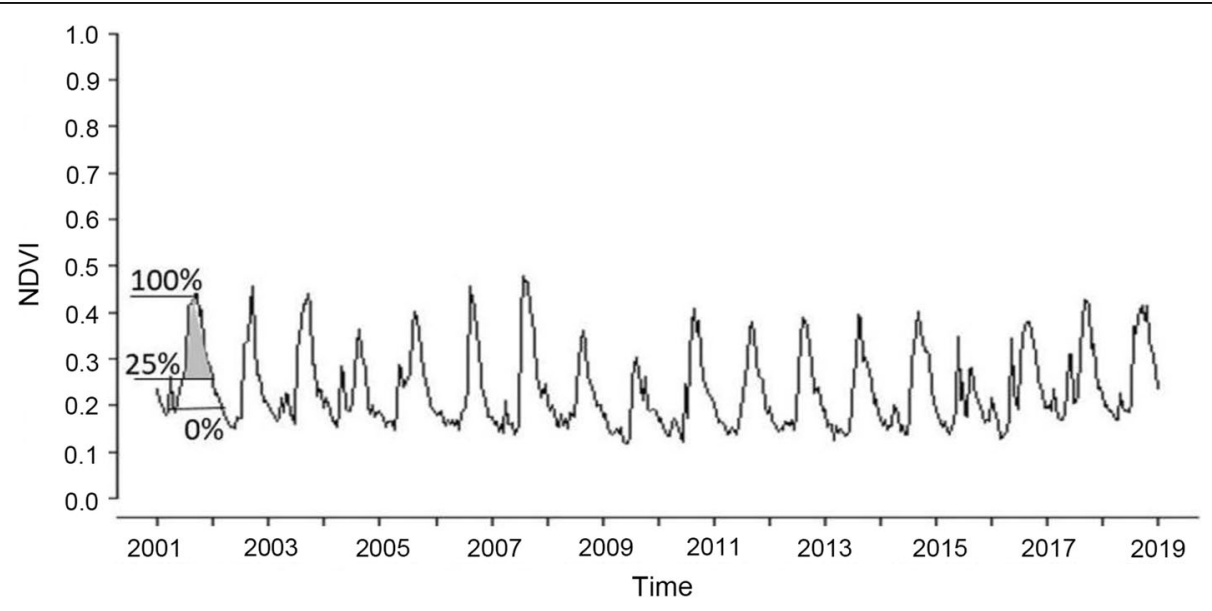

Fig. 4 Fraction of the yearly NDVI (75\%) used to extract growth stability for Desa'a forest 
applied to the stability metrics obtained on a plot level. Similarly, the stability matrices were summarized on an annual basis to show the stability status of the forest over the study period. A summary of the methodological approach is presented in the flow chart below (Fig. 5).

\section{Results}

\section{Stability status of Desa'a forest and correlation of the metrics}

The resilience, resistance, and growth stability of Desa'a forest from 2001 to 2018 depict a similar trend (Figs. 5 and 6, Table 2). The resilience index showed lows in the years 2001, 2007 and 2015 (Fig. 6). The resistance showed minima in 2004, 2008, 2009 and 2015. The growth stability, however, was declining throughout the study period except for a sudden rise in 2016 (Fig. 7). Additionally, the spatial distribution of the four metrics showed similar patterns (Fig. 8), where vegetation in the south was more stable while in the center of the study area it was less stable. In the north, however, it was more stable except for the resilience metric.

The correlation between the stability metrics used shows that resilience $(r=0.56)$ and resistance $(r=0.46)$ correlated significantly with growth stability. However, the correlation between resistance and resilience was weak (0.23). The correlation among resilience, resistance and productivity was positive.

\section{Drivers of stability \\ Drivers of resilience}

Resilience was influenced by a combination of biophysical and climatic factors. In general, precipitation of the wettest month, species evenness, distance from the settlement and slope were the most effective variables explaining the resilience of Desa'a forest. The other factors had a similar share of influence (Table 2).

The partial dependencies of the variables in the model indicated that three main types of responses could be observed. First, the precipitation of the wettest month, annual precipitation, annual temperature, Shannon diversity, distance to settlement, and annual temperature range showed a similar trend. Their influence was increasing up to a certain optimal condition and ceiled afterwards. In all except the precipitation of the wettest month, visible reductions in resilience were observed before an ultimate increment was recorded. Second, the effect of both species evenness and slope showed a unimodal shape, high at the mid values and lower at the two ends. Third, temperature seasonality and stoniness showed a negative effect on the resilience of the forest (Fig. 9).

\section{Drivers of resistance}

Temperature seasonality and temperature of the driest quarter, forest floor thickness and precipitation of the wettest month were the variables that influenced the resistance of the forest most, with a total contribution of $53.6 \%$ (Table 3).

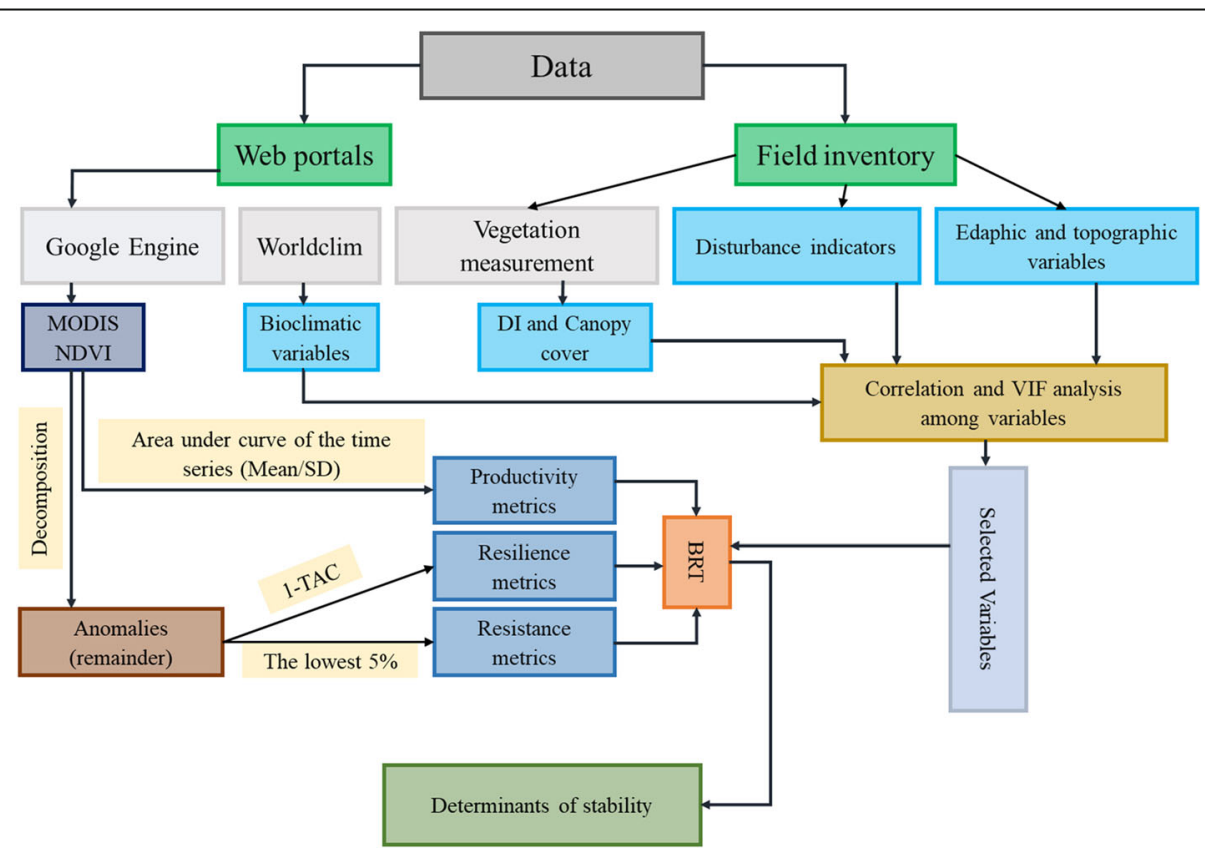

Fig. 5 Methodological flowchart showing the workflow used in this paper. DI is Diversity indices, VIF is variance inflation factor, TAC is temporal autocorrelation, SD is the standard deviation, and BRT is boosted regression tree. Same colours show similar work stages; blue represents final input variables and green data sources, for example 


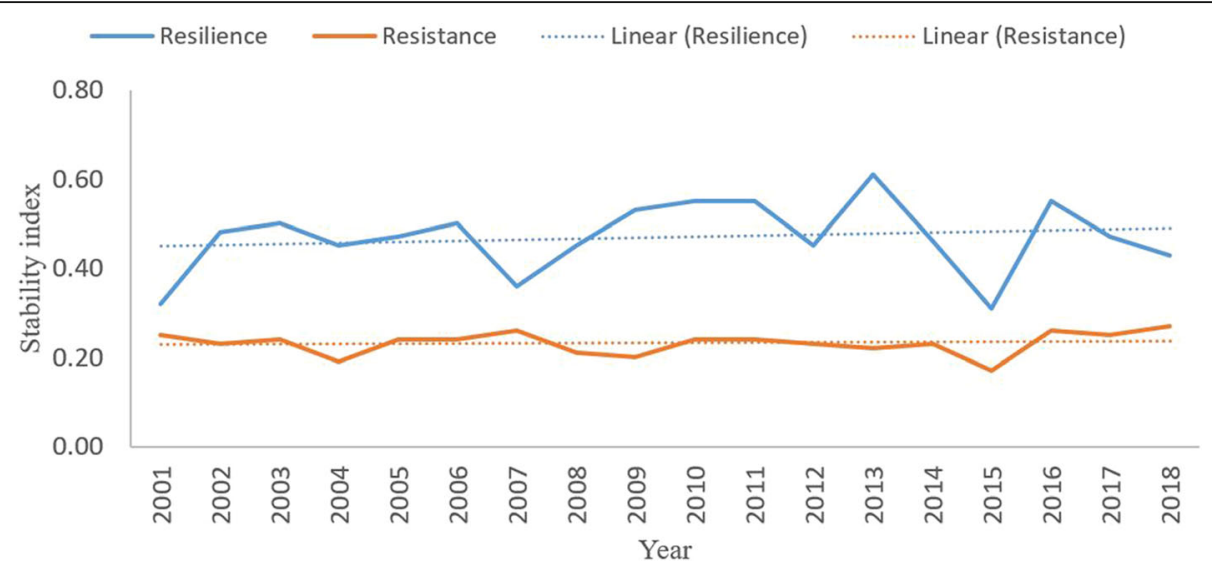

Fig. 6 The NDVI derived resilience and resistance of Desa'a Forest between 2001 to 2018. The solid line is the average of each metrics of all plots in a particular year and the broken line is the linear trendline of each metric

The partial dependency plots revealed that the important variables affecting resistance had two general effect trends. First, the influence of temperature seasonality ended up in a decreasing trend though they showed different responses in the process. The resistance of the forest was lower in areas where temperature seasonality was lower than $180\left(1.8^{\circ} \mathrm{C}\right)$, the optimal size of temperature seasonality and got pick at around $220\left(2.2^{\circ} \mathrm{C}\right)$ above which an increase in temperature seasonality resulted in reduced resistance of forest communities. Second, the effect of the mean temperature of the driest quarter, humus depth and precipitation of the wettest month followed a positive trend. Around $185 \mathrm{~mm}$ precipitation of the wettest month is optimal to keep a resistant forest in the dry Afromontane environment (Fig. 10).

\section{Drivers of growth stability}

Growth stability was governed dominantly by precipitation of the wettest month, taking about $44 \%$ of the total effect. Annual temperature range, precipitation of the warmest quarter and distance to settlement had similar effect strength accounting for $56 \%$ of the total (Table 4 ).
The partial dependencies of the factors influencing growth stability (Fig. 11) show that the stability of the forest has been increasing with all the important factors. However, the increment rate was different across the factors. The growth stability remained low up to around 155 $\mathrm{mm}$ of precipitation of the wettest month, and it exponential increased and ultimately ceiled at $180 \mathrm{~mm}$ (Fig. 11).

\section{Model strength of the different stability metrics}

The performance of the model fit to the different stability metrics is given in Table 5. Modelling growth stability with the variables used was difficult compared to the other response variables, resulting in the lowest performance for all goodness-of-fit criteria used (Table 5).

\section{Discussion}

Resilience, resistance and growth stability status of Desa'a forest

Over the study period, Desa'a Forest remained more or less resistant but not resilient, with a significant decrease in resilience in 2001, 2007 and 2015. A slight drop below the average resistance was also observed in 2004, 2008,

Table 2 The relative influence of the variables determining resilience in Desa'a forest (in bold are significant factors)

\begin{tabular}{lll}
\hline Variable & Relative influence (\%) & Optimal value \\
\hline Precipitation of the wettest month & $\mathbf{1 5 . 7}$ & $\mathbf{1 7 5} \mathbf{~ m m}$ \\
BA Evenness & $\mathbf{1 2 . 9}$ & $\mathbf{0 . 7}$ \\
Distance from a settlement & $\mathbf{1 2 . 8}$ & $\mathbf{5} \mathbf{~ k m}$ \\
Slope & $\mathbf{1 0 . 9}$ & $\mathbf{1 8 ~ d e g r e e s}$ \\
Annual precipitation & 10.1 & $650 \mathrm{~mm}$ \\
Shannon diversity index & 9.9 & 1.5 \\
Temperature seasonality & 9.5 & $1.8^{\circ} \mathrm{C}$ \\
Temperature annual range & 9.3 & $22.5^{\circ} \mathrm{C}$ \\
Stoniness & 8.9 & $10 \%$ \\
\hline
\end{tabular}




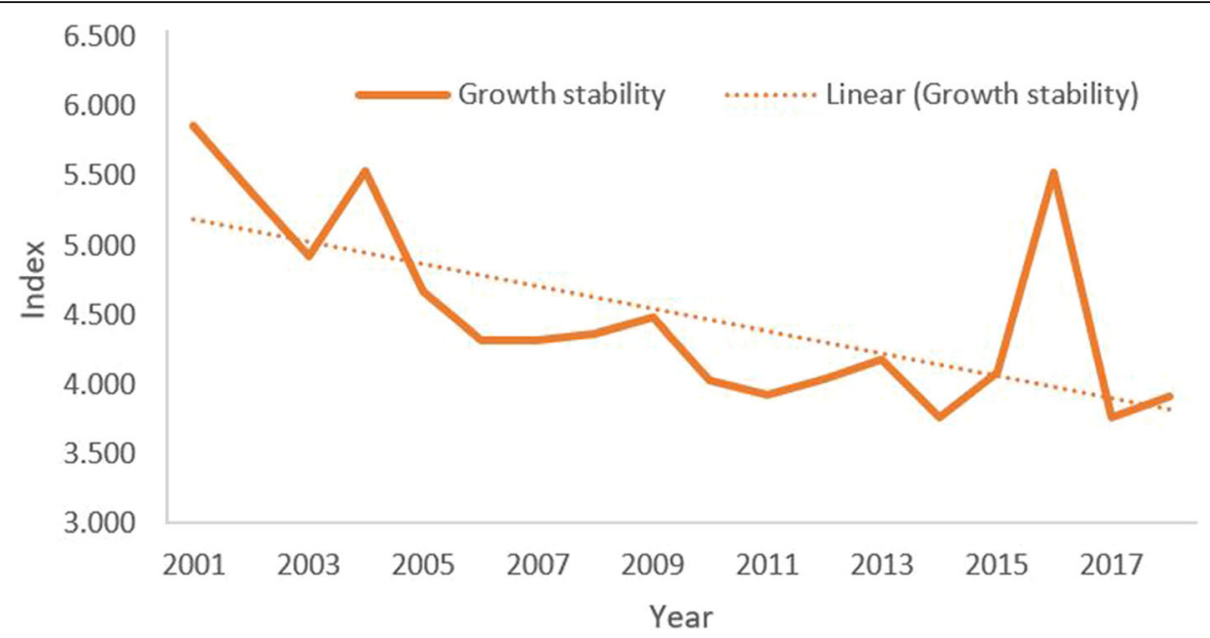

Fig. 7 Growth stability in Desa'a Forest, 2001 to 2018. The solid line is the average growth stability of all plots in a particular year and the broken line is the linear trend of the growth stability

2009, and 2015. The frequent, and acute drought occurrences might explain these drops in both resilience and resistance in the region. In the study period, reported droughts occurred in 2000, 2002, 2004 (Gebrehiwot and van der Veen 2013), 2012 and 2013 (Tefera et al. 2019), and 2015 (Ahmed et al. 2017). The resilience range of Desa'a forest (0.3-0.6) is incomparably lower than that of other African tropical forests (0.7-1.0) reported by Verbesselt et al. (2016) which might explain the severe and repetitive anthropogenic pressure the forest is facing (Aynekulu et al. 2011). The growth stability, however, was continuously decreasing over the study period, which might be linked to continuous degradation in the forest that could be explained by the dieback of the dominant species, olive and juniper trees (Aynekulu et al. 2011), browsing and lopping of various species (Giday et al. 2018). The frequent drought occurrences that were linked to the declined resilience of the forest

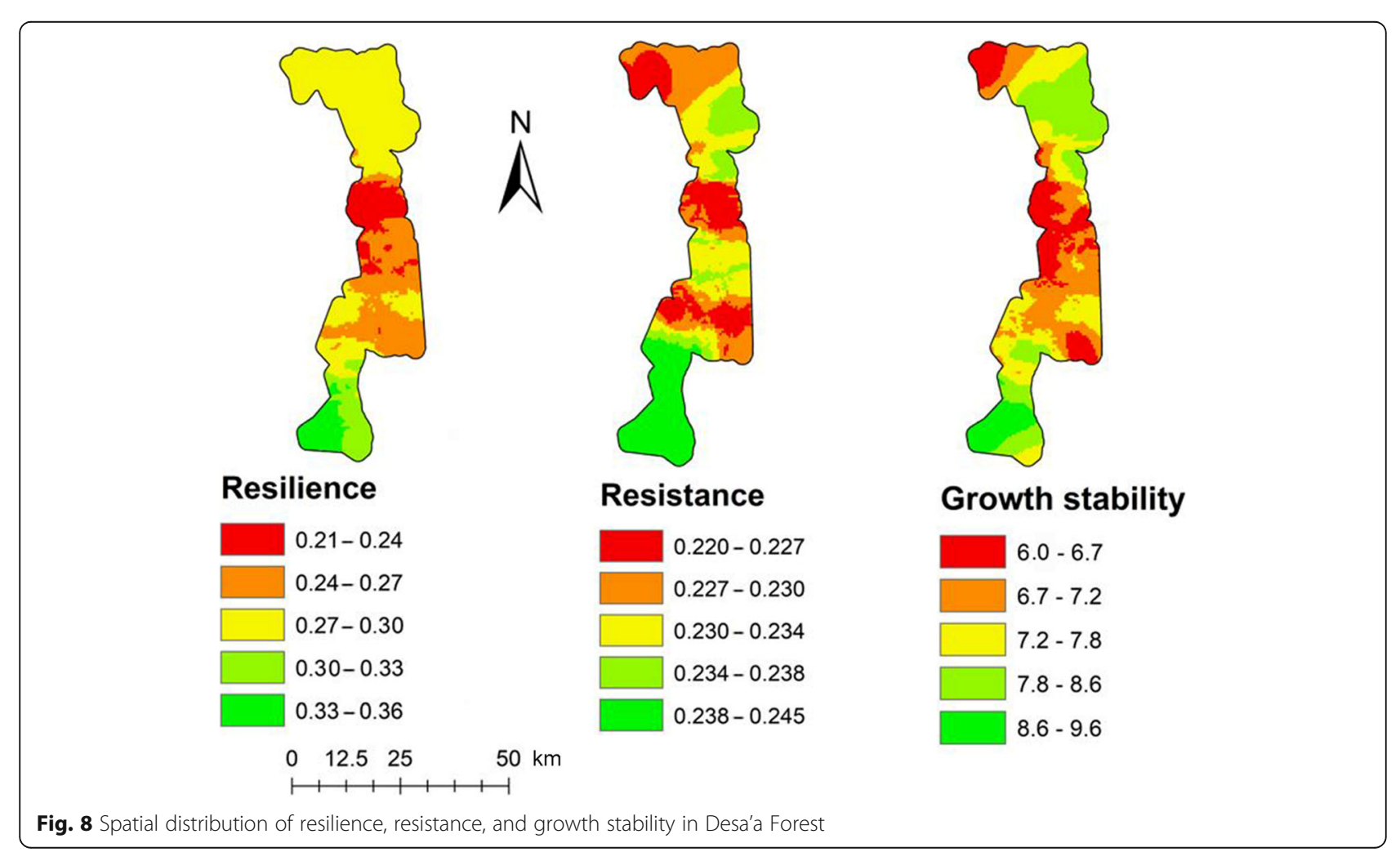



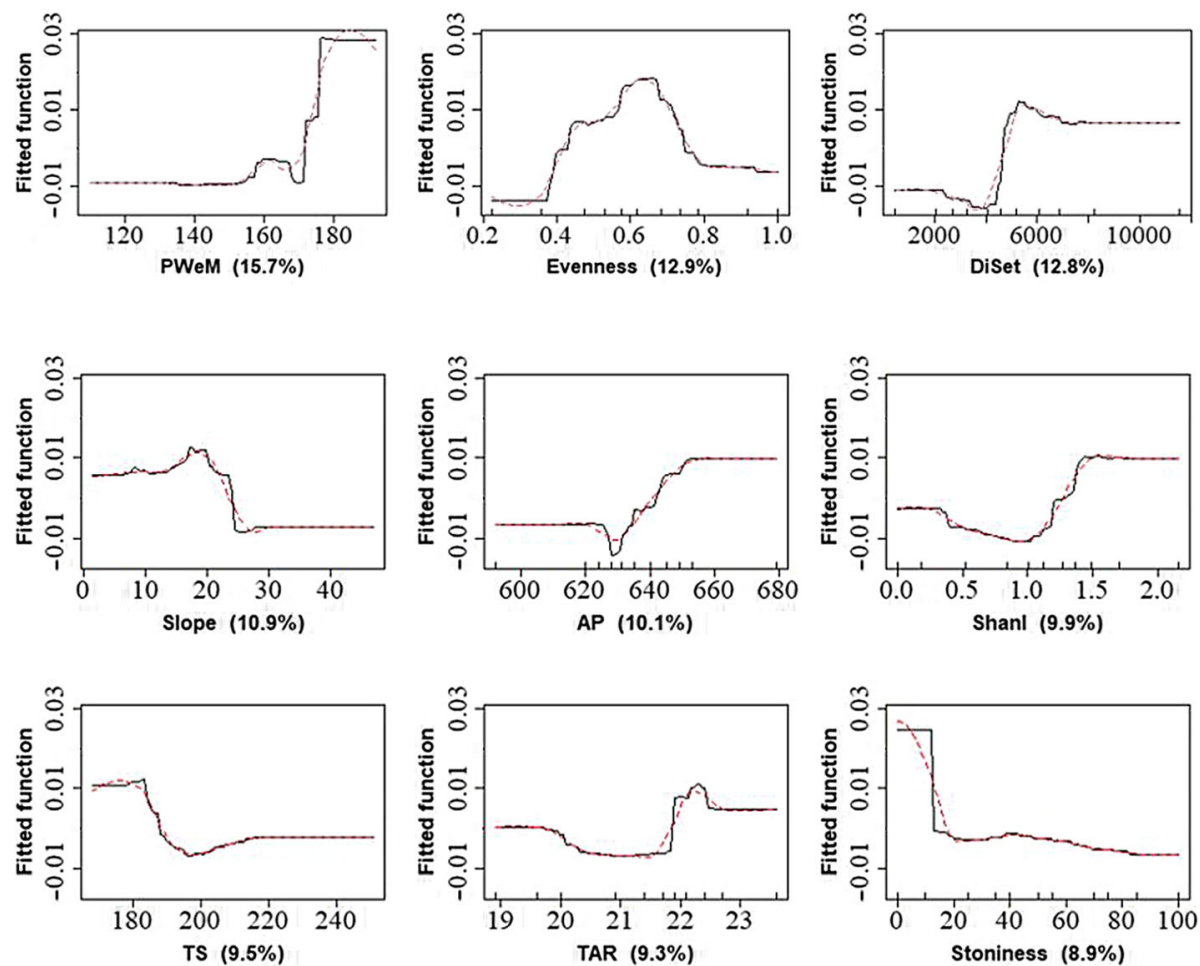

Fig. 9 Partial dependencies of factors affecting resilience in Desa'a forest. The relative importance of variables in the model (\% out of 100) is given in brackets. Fitted functions are centred around the mean of the resilience and plotted on a common scale. Rug plots (ticks in X-axis) show the distribution of sample measurements. PWem stands for precipitation of the wettest month, DiSet for distance from the settlement, AP for annual precipitation, Shanl for Shannon index, TS for temperature seasonality and TAR for temperature annual range

might also be a reasonable explanation for the decreased yield stability. A clear increment of growth was, however, observed in 2016. This might be attributed to the increased rainfall recorded in 2016 (Berhane et al. 2020). Because there was an acute drought in 2015 (Ahmed et al. 2017) and significant increment in precipitation in 2016, growth might have positively affected the biomass production in the forest.

Among the determinants of resilience, resistance, and growth stability, those above the median in the contribution of the factors are considered important (significant) factors (Gu et al. 2019) and are discussed.

\section{Drivers of forest resilience}

Precipitation of the wettest month was the most important factor associated with resilience. Although dry forests in the tropics are generally considered more resilient, their recovery is heavily dependent on the amount of precipitation (Álvarez-Yépiz et al. 2018), which is in line with the results of this study. A similar result was also reported in a wide range of tropical forest ecosystems where extended drought and low precipitation slows the recovery of forests in different continents (Verbesselt et al. 2016) and Amazon mountain forests (Nobre and Borma 2009).

Table 3 The relative influence of the variables determining resistance in Desa'a Forest (in bold are significant factors)

\begin{tabular}{lll}
\hline Variables & Relative importance (\%) & Optimal value \\
\hline Temperature seasonality & $\mathbf{1 9 . 4}$ & $\mathbf{2 . 2 ^ { \circ } \mathrm { C }}$ \\
Mean temperature of the driest quarter & $\mathbf{1 9 . 3}$ & $\mathbf{2 0}{ }^{\circ} \mathrm{C}$ \\
Humus depth & $\mathbf{1 4 . 9}$ & $\mathbf{2} \mathbf{c m}$ \\
Precipitation of the wettest month & $\mathbf{1 3 . 9}$ & $\mathbf{1 8 5} \mathbf{~ m m}$ \\
Temperature annual range & 10.9 & $21.5^{\circ} \mathrm{C}$ \\
Stoniness & 10.8 & $30 \%$ \\
Isothermality & 10.7 & $72 \%$ \\
\hline
\end{tabular}



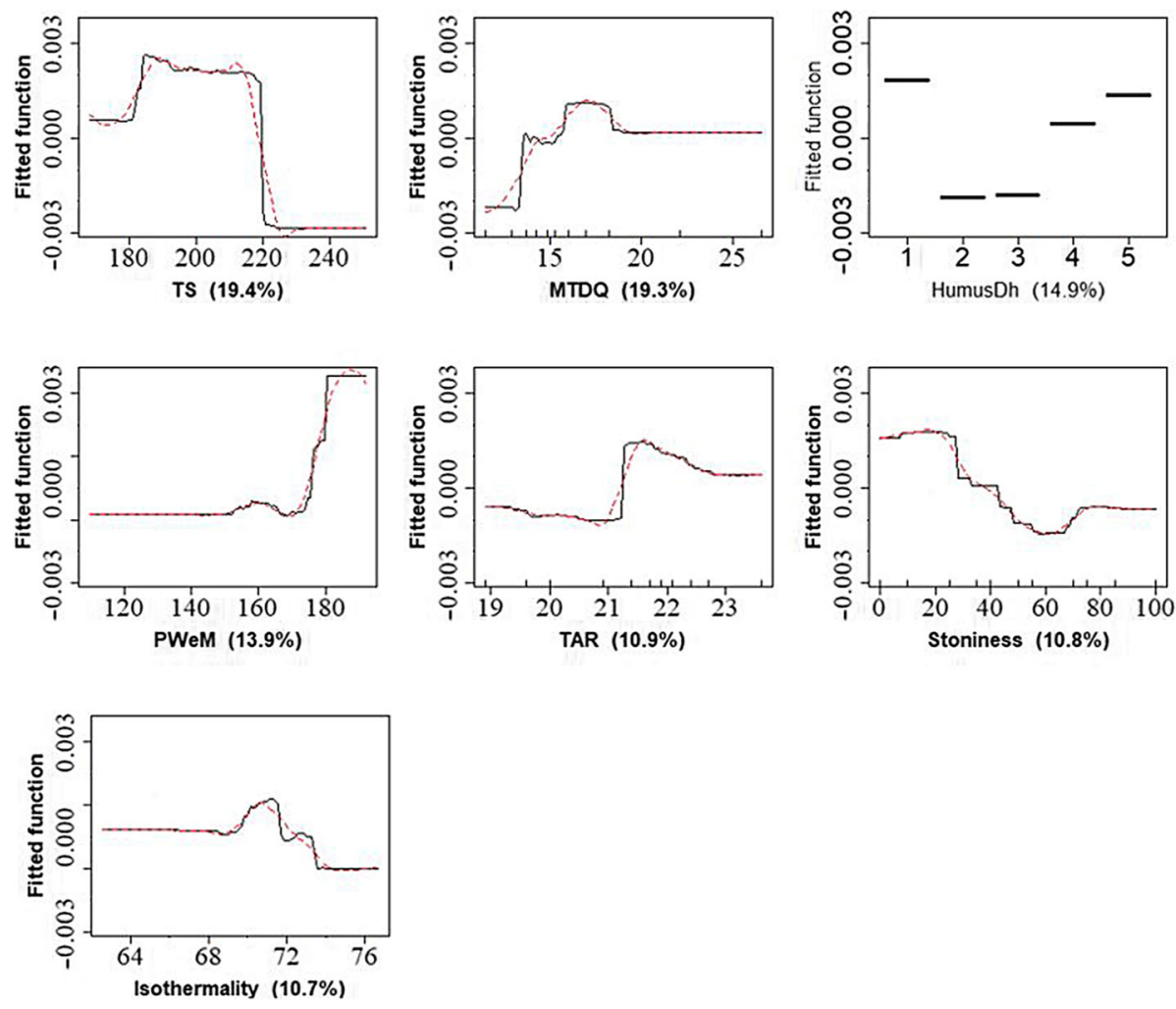

Fig. 10 Partial dependencies of factors affecting resistance in Desa'a forest. The relative importance of variables in the model (\% out of 100) is given in brackets. Fitted functions are centred around the mean of the resilience and plotted on a common scale. Rug plots (ticks in X-axis) show the distribution of sample measurements. TS stands for temperature seasonality, MTDQ for a mean temperature of the driest quarter, HumusDh for humus depth, PWeM for precipitation of the wettest month, and TAR for temperature annual range

Generally, tree diversity was associated with resilience, yet the Shannon and evenness indicators had a different impact. In the literature, there are contradicting findings on the effect of diversity on stability, where positive effect of species diversity has been reported in grasslands (Tilman et al. 2006; Van Ruijven and Berendse 2010), and in forests across Europe (Guyot et al. 2016, SousaSilva et al. 2018, Vannoppen et al. 2019), while others argue that there is no true positive diversity effect found so far on resilience (Bauhus et al. 2017). We found a positive association of Shannon diversity with resilience, but saturating eventually. The positive effect of diversity on resilience might be explained by the insurance effect where different species respond differently to disturbances stabilizing the overall resilience as a system regardless of the lowered performance of certain member species (Loreau 2004). However, the effect of evenness was unimodal, with the highest evenness values resulting in a lower forest resilience. In this forest, dominant species might be needed to some extent to keep the forest community more resilient. Such species could have particular functional traits that play a significant role in the stability of the forest community (Yan et al. 2011). However, diversity indices lack information to indicate the functional role of species (Yan et al. 2011) and limit the identification of the species that are disadvantaged when sites get more even. In Desa'a Forest, such late successional species could be those that are less competitive such as juniper tree (Alshahrani 2008), which are disadvantaged when they grow in even proportion to others, reducing the total resilience of the forest community.

Table 4 The relative influence of the variables determining growth stability in Desa'a forest (in bold are significant factors)

\begin{tabular}{lll}
\hline Variable & Relative influence (\%) & Optimal value \\
\hline Precipitation of the wettest month (PWeM) & $\mathbf{4 3 . 5 2}$ & $\mathbf{1 7 5} \mathbf{~ m m}$ \\
Temperature annual range (TAR) & $\mathbf{2 0 . 5 2}$ & $\mathbf{2 2 . 5 ^ { \circ } \mathrm { C }}$ \\
Precipitation of the warmest quarter (PWaQ) & 19.25 & $240 \mathrm{~mm}$ \\
Distance to settlement (DiSet) & 17.61 & $6000 \mathrm{~m}$ \\
\hline
\end{tabular}



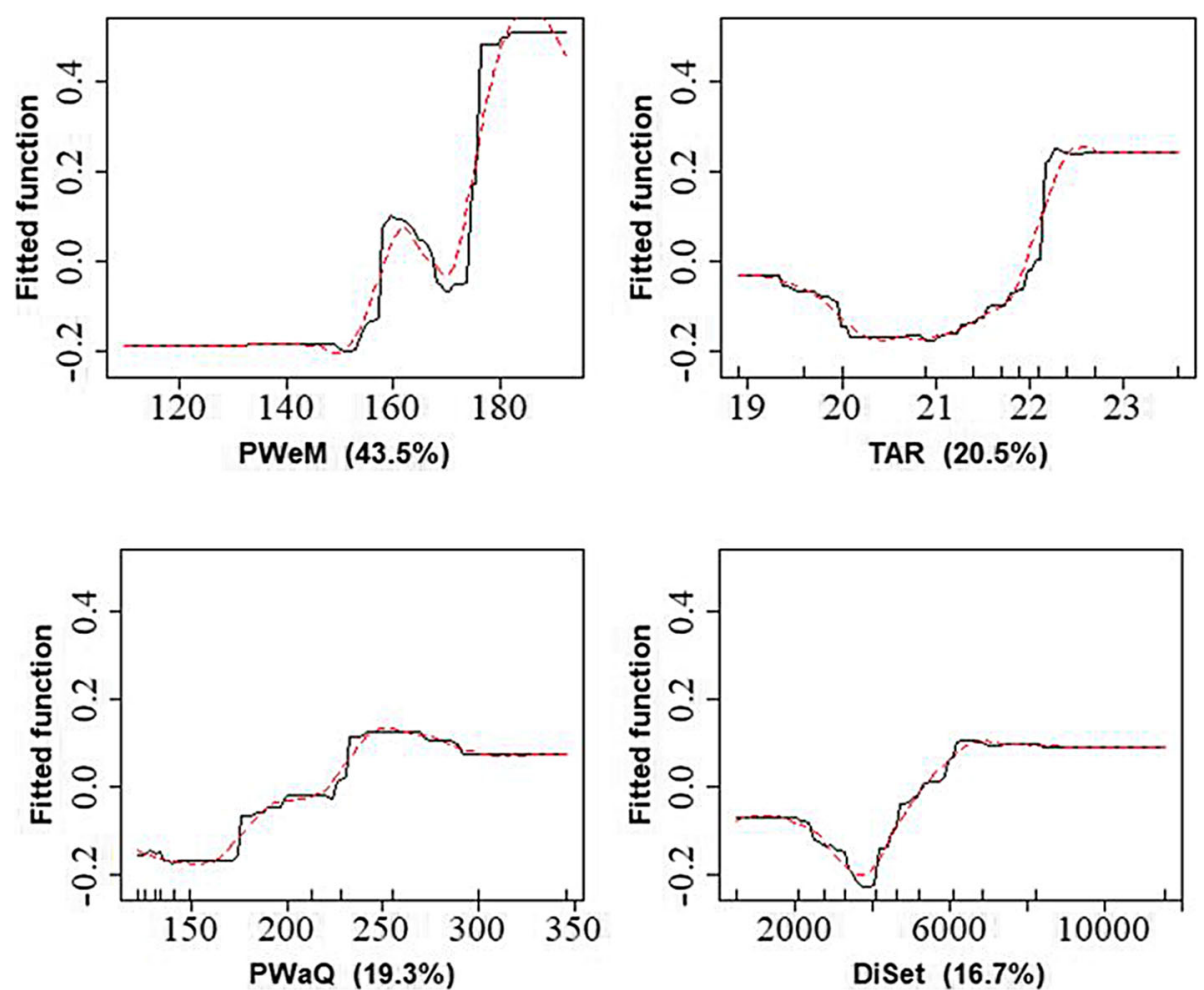

Fig. 11 Partial dependencies of factors affecting growth stability in Desa'a forest. The relative importance of variables in the model (\% out of 100) is given in brackets. Fitted functions are centred around the mean of the growth stability and plotted on a common scale. Rug plots (ticks in $X$ axis) show the distribution of sample measurements. PWeM stands for precipitation of the wettest month, TAR for temperature annual range, PWaQ for precipitation of the warmest quarter and DiSet for distance to settlement

Proximity to a settlement increases the probability of anthropogenic disturbance such as grazing and cutting, which are predominant in the forest (Giday et al. 2018). Our results confirm that the resilience of the vegetation located further than $5 \mathrm{~km}$ from settlements was considerably increased. The anthropogenic disturbance could affect resilience by affecting species composition, which might introduce an artificial dominance of a certain tree species and reduce species richness. That could have a direct impact on the resilience of the forest (Hillebrand et al. 2008).

The negative effect of slope on the resilience might be linked to its effect on soil depth, moisture content and susceptibility to degradation where steep slopes and exposed rocky areas have a little medium for plant growth

Table 5 Stability metrics and their model performance (TDC is training data correlation, CVC is cross-validation correlation)

\begin{tabular}{llll}
\hline Criteria & Resilience & Resistance & Growth stability \\
\hline RMSE & 0.04 & 0.01 & 1.60 \\
$R^{2}$ & 0.74 & 0.6 & 0.38 \\
AIC & -395 & -577 & 65 \\
TDC & 0.86 & 0.78 & 0.60 \\
CVC & 0.32 & 0.34 & 0.20 \\
\hline
\end{tabular}

due to erosion (Zhang et al. 2015), and when disturbances prevail, they are more affected than those in good soil conditions and gentle slopes. In general, in line to our hypotheses, the combination of tree diversity, local human impact, topographic position and climate (mainly precipitation) controlled resilience in dry Afromontane forest.

\section{Drivers of resistance}

While temperature seasonality was negatively associated with resistance, mean temperature of the driest quarter, humus thickness and precipitation of the wettest month was positively associated. In contrary to resilience, the resistance of forests is dependent more on their productivity before a disturbance (Wang et al. 2007; Van Ruijven and Berendse 2010). Therefore, forest communities growing in productive sites, having favourable environmental conditions, are expected to show higher resistance (Wang et al. 2007). In line with this argument, our results indicated that vegetation growing in sites with thicker humus and more stony sites had higher and lowered resistance, respectively. The negative effect of increased temperature seasonality on forest resistance might be a general attribute to the tropical forests which have developed themselves under relatively stable 
climatic conditions (Blach-Overgaard et al. 2010). Therefore, in response to their narrow climatic tolerance, as the seasonality of temperature increases, forests might lose the capacity to rearrange (to adapt quickly) themselves so reducing their resilience capability (BlachOvergaard et al. 2010). Our results indicate that higher temperature seasonality and annual temperature range were associated with lower resistance. In the highland parts of Desa'a Forest, where it is relatively colder and dominated by climax species, a negative correlation between temperature and growth of juniper and olive trees was reported (Mokria et al. 2017; Siyum et al. 2019). Temperature seasonality between $1.8^{\circ} \mathrm{C}$ and $2.2^{\circ} \mathrm{C}$ and an annual temperature range between $21^{\circ} \mathrm{C}$ and $22^{\circ} \mathrm{C}$ were associated with higher resilience. Increased temperature seasonality and annual temperature range prolongs the disturbance and slows the recovery and break the resistance (Anjos and De Toledo 2018) due to increased fluctuation and excessive evapotranspiration (Schroth et al. 2009).

In contrast to the resilience indicator, no association between biodiversity and resistance could be found. This is in line with the findings of Van Ruijven and Berendse (2010) who reported the positive effect of biodiversity on community resilience after a drought, but there was no association found with resistance. This is another strong evidence that resistance to disturbance depends on a prior forest condition (production, health, etc.). In contrast, the post-disturbance response of the forest could be supported by its constituents, such as diversity (Van Ruijven and Berendse 2010). While our hypothesis on the positive effect of climate and good edaphic properties on resistance holds true, the effect of tree diversity was not supported by our results.

\section{Drivers of growth stability}

The growth stability was mainly controlled by climate, the precipitation of the wettest month. The effect of tree diversity was not observed, and only the distance to settlement as an indicator of human impact indicator was detected though not significant. In dry forests, precipitation is the most important factor for the growth of trees and increased biomass (Hiltner et al. 2016). Dry forests are affected by high evapotranspiration due to the high temperature and low precipitation (Souza et al. 2016), and when precipitation gets higher, the growth of the forests is positively affected. The results are in line with the findings from different tropical forests; subtropical forest in China (Gu et al. 2019), dry tropical montane forests of Ethiopia (Hiltner et al. 2016), and in the dry Afromontane forests (Gebru et al. 2020). Effect of anthropogenic disturbances can be mediated and suppressed by the effect of precipitation which initiates more growth and system repair in forests (Rito et al.
2017), which could be the reason for the non-significant effect of disturbance on the growth stability of this forest.

\section{The relationship among resilience, resistance and growth stability in Desa'a forest}

Forest stability was successfully characterized using resilience and resistance from remotely sensed imagery in different forests (Sousa-Silva et al. 2018; Frazier et al. 2018). In Desa'a, a dry tropical Afromontane forest, the three stability metrics were modeled. The correlation analysis between the metrics showed that the correlation between resilience and resistance was very weak but positive. This is in line with the concept of DeRose and Long (2014), who argued that resistance and resilience act upon ecosystems differently. While resilience is related to the influence of disturbance on the structure and composition of the ecosystem, resistance is related to the influence of the structure and composition of an ecosystem on disturbance. In support of our results, Gazol et al. (2018) reported low resistant forests to be more resilient across different biomes. Against our findings, a negative correlation was found between resistance and recovery rate from another tropical dry forest (Bhaskar et al. 2018). The difference in the correlation results might be due to the difference in the interaction of climate and local degradation factors (Bhaskar et al. 2018).

\section{Conclusion and recommendation}

The dry Afromontane forest of Desa'a was generally resistant but less resilient experiencing a continuous decline growth in stability in the last two decades. Climate variability played a pivotal role in the resilience, and resistance of the forest. While the precipitation of the wettest month is the most important factor in all the stability metrics, an inter-annual variation above $2{ }^{\circ} \mathrm{C}$ is was enough to degrade the resilience and resistance of the forest. Furthermore, tree species diversity was important to enhance the resilience of the dry Afromontane forest, but no evidence of tree diversity effects was found for resistance and growth stability. We found a threshold (0.7), above which tree species evenness leads to less resilience. Experimental research might be important to investigate into what extent of evenness species identity is important to promote resilience in the dry forests. Moreover, distance to the settlement, which is an indicator of degradation and slope were also important to promote resilience. Climate, both precipitation and temperature, edaphic factors, local human disturbance indicators and tree diversity were important for one or all of the stability metrics investigated in the dry Afromontane forest. 


\section{Supplementary Information}

The online version contains supplementary material available at https://doi. org/10.1186/s40663-021-00288-x.

Additional file 1 : Appendix 1. Methodological protocol for humus, soil depth, and local human disturbance indicators assessment.

\section{Acknowledgements}

Forest inventory data were obtained from WeForest, an international nonprofit non-government organization, which is working on the restoration of Desa'a forest in collaboration with different national and international institutes (https://www.weforest.org/project/ethiopia-desaa).

\section{Authors' contributions}

Conceptualization: HH \& BM; Methodology: HH \& BM; Formal Analysis: HH \& LO; Writing - original draft: HH; Writing review \& editing: BM, BS, WD \& KG; Supervision: BM. The author(s) read and approved the final manuscript.

\section{Funding}

PhD IRO grant from KU Leuven and WeForest Ethiopia supported the data collection. It is one of the chapters of a PhD research and there is no specific ID attached to the funds.

\section{Availability of data and materials}

The datasets generated during and/or analyzed during the current study are available in the KU Leuven repository, and are accessible according to the regulation of the University.

\section{Ethics approval and consent to participate}

Not applicable.

\section{Consent for publication}

Not applicable.

\section{Competing interests}

The authors declare that they have no competing interests.

\section{Author details}

${ }^{1}$ KU Leuven, Department of Earth and Environmental Sciences, Division Forest, Nature and Landscape, Celestijnenlaan 200E, P.O. Box 2411, 3001 Leuven, Belgium. ${ }^{2}$ Department of Land Resource Management and Environmental Protection, Mekelle University, College of Dryland Agriculture and Natural Resources, P.O. Box 231, Mekelle, Tigray, Ethiopia. ${ }^{3}$ Laboratory of Geo-Information Science and Remote Sensing, Wageningen University, 6708 PB Wageningen, The Netherlands.

\section{Received: 4 October 2020 Accepted: 18 January 2021}

\section{Published online: 22 February 2021}

\section{References}

Abbes A, Bounouh O, Farah IR, de Jong R, Martínez B (2018) Comparative study of three satellite image time-series decomposition methods for vegetation change detection. Eur J Remote Sens 51(1):607-615. https://doi.org/10.1080/ 22797254.2018 .1465360

Abrha H, Adhana K (2019) Desa'a national forest reserve susceptibility to fire under climate change. Forest Sci Tech 15(3):140-146. https://doi.org/10.1080/ 21580103.2019.1628109

Aertsen W, Kint V, de Vos B, Deckers J, van Orshoven J, Muys B (2012) Predicting forest site productivity in temperate lowland from forest floor, soil and litterfall characteristics using boosted regression trees. Plant and Soil 354(12):157-172. https://doi.org/10.1007/s11104-011-1052-z

Ahmed H, Tessema Z, Adugna T, Diriba K (2017) Interconnection between ElNiño-southern oscillation induced rainfall variability, livestock population dynamics and pastoralists adaptation strategies in eastern Ethiopia. Proc Int Conf Impact El Niño Biodivers, Agric Food Security 7(February):19-36 http:// www.haramaya.edu.et. Accessed 6 Sep 2020

Aide TM, Clark ML, Grau HR, López-Carr D, Levy MA, Redo D, Bonilla-Moheno M, Riner G, Andrade-Núñez MJ, Muñiz M (2013) Deforestation and reforestation of latin america and the caribbean (2001-2010). Biotropica 45(2):262-271. https://doi.org/10.1111/j.1744-7429.2012.00908.x
Alshahrani TS (2008) Effect of aqueous extract of the invasive species tobacco (Nicotiana glauca L.) on seedlings growth of Juniper (Juniperus procera L.) Emir J Food Agr 20(2):10-17

Álvarez-Yépiz JC, Martínez-Yrízar A, Fredericksen TS (2018) Special issue: resilience of tropical dry forests to extreme disturbance events. Forest Ecol Manag 426: 1-6. https://doi.org/10.1016/j.foreco.2018.05.067

Anjos LJS, De Toledo PM (2018) Measuring resilience and assessing the vulnerability of terrestrial ecosystems to climate change in South America. PLoS One 13(3):1-15. https://doi.org/10.1371/journal.pone.0194654

Asrat A (2002) The rock-hewn churches of Tigrai, northern Ethiopia: a geological perspective. Geoarchaeol 17(7):649-663. https://doi.org/10.1002/gea.10035

Aynekulu E, Aerts R, Moonen P, Denich M, Gebrehiwot K, Vågen TG, Wolde W, Boehmer HJ (2012) Altitudinal variation and conservation priorities of vegetation along the great Rift Valley escarpment, northern Ethiopia. Biodivers Conserv 21(10):2691-2707. https://doi.org/10.1007/s10531-012-0328-9

Aynekulu E, Denich M, Tsegaye D, Aerts R, Neuwirth B, Boehmer HJ (2011) Dieback affects forest structure in a dry Afromontane forest in northern Ethiopia. J Arid Environ 75(5):499-503. https://doi.org/10.1016/j.jaridenv.2010.12.013

Bargués-Tobella A, Hasselquist NJ, Bazié HR, Bayala J, Laudon H, Ulrik Ilstedt U (2020) Trees in African drylands can promote deep soil and groundwater recharge in a future climate with more intense rainfall. Land Degrad Dev 31(1):81-95. https://doi.org/10.1002/ldr.3430

Bastin JF, Nora B, Alan G, Danae M, Danilo M, Rebecca M, Chiara P, Nicolas P, Ben S, Elena MA, Kamel A, Ayhan A, Fabio AB, Çağlar B, Adia B, Monica G, Luis GG, Nikée G, Greg G, Lars L, Andrew JL, Bako M, Giulio M, Paul P, Marcelo R, Stefano R, Ignacio S, Alfonso SD, Fred S, Venera S, Rene C (2017) The extent of forest in dryland biomes. Science 358(6365):635-638. https:/doi.org/10.1126/science.aao1309

Bauhus J, Forrester DI, Gardiner B, Jactel H, Vallejo R, Pretzsch H (2017) Ecological stability of mixed-species forests. In: Pretzsch H, Forrester DI, Bauhus J (eds) Mixed-Species Forests: Ecology and Management. Springer Berlin Heidelberg, Berlin. https://doi.org/10.1007/978-3-662-54553-9_7

Berhane A, Hadgu G, Worku W, Abrha B (2020) Trends in extreme temperature and rainfall indices in the semi-arid areas of Western Tigray, Ethiopia. Environ Syst Res 9(1). https://doi.org/10.1186/s40068-020-00165-6.

Bhaskar R, Arreola F, Mora F, Martinez-Yrizar A, Martinez-Ramos M, Balvanera P (2018) Response diversity and resilience to extreme events in tropical dry secondary forests. Forest Ecol Manag 426:61-71. https://doi.org/10.1016/j. foreco.2017.09.028

Blach-Overgaard A, Svenning JC, Dransfield J, Greve M, Balslev H (2010) Determinants of palm species distributions across Africa: the relative roles of climate, non-climatic environmental factors, and spatial constraints. Ecography 33(2):380-391. https://doi.org/10.1111/j.1600-0587.2010.06273.x

Bognounou F, Tigabu M, Savadogo P, Thiombiano A, Boussim IJ, Oden PC, Guinko S (2010) Regeneration of five Combretaceae species along a latitudinal gradient in Sahelo-Sudanian zone of Burkina Faso. Ann Forest Sci 67(3):10. https://doi.org/10.1051/forest/2009119

Chen C, He B, Yuan W, Guo L, Zhang Y (2019) Increasing interannual variability of global vegetation greenness. Environ Res Lett. https:/doi.org/10.1088/1748-9326/ab4ffc

Dakos V, Carpenter SR, Brock WA, Ellison AM, Guttal V, Ives AR, Kéfi S, Livina V, Seekell DA, Van Nes EH, Scheffer M (2012) Methods for detecting early warnings of critical transitions in time series illustrated using simulated ecological data. PLoS One 7(7). https://doi.org/10.1371/journal.pone.0041010

De Keersmaecker W, Lhermitte S, Honnay O, Farifteh J, Somers B, Coppin P (2014) How to measure ecosystem stability? An evaluation of the reliability of stability metrics based on remote sensing time series across the major global ecosystems. Glob Chang Biol 20(7):2149-2161. https://doi.org/10.1111/gcb.12495

De Keersmaecker W, Lhermitte S, Tits L, Honnay O, Somers B, Coppin P (2018) Resilience and the reliability of spectral entropy to assess ecosystem stability. Glob Chang Biol 24(1):e393-e394. https://doi.org/10.1111/gcb.12799

DeRose RJ, Long JN (2014) Resistance and resilience: a conceptual framework for silviculture. For Sci 60(6):1205-1212. https://doi.org/10.5849/forsci.13-507

Díaz S, Pascual U, Stenseke M, Martín-López B, Watson RT, Molnar Z, Hill R, Chan KMA, Baste IA, Brauman KA, Polasky S, Church A, Lonsdale M, Larigauderie A, Leadley PW, van Oudenhoven APE, van der Plaat F, Schroter M, Lavorel S, Aumeeruddy-Thomas Y, Bukvareva E, Davies K, Demissew S, Erpul G, Failler P, Guerra CA, Hewitt CL, Keune H, Lindley S, Shirayama Y (2018) Assessing nature's contributions to people. Science 359(6373):270-272. https://doi.org/ 10.1126/science.aap8826

Duffy JE, Godwin CM, Cardinale BJ (2017) Biodiversity effects in the wild are common and as strong as key drivers of productivity. Nature 549(7671):261264. https://doi.org/10.1038/nature23886 
Elith J, Leathwick JR, Hastie T (2008) A working guide to boosted regression trees. J An Ecol 77(Ml):802-813. https://doi.org/10.1111/j.1365-2656.2008. 01390.x

Eriksson CP, Holmgren P (1996) Estimating stone and boulder content in forest soils - evaluating the potential of surface penetration methods. Catena 28(12):121-134. https://doi.org/10.1016/S0341-8162(96)00031-8

FAO (2010) Global Forest Resources Assessment 2010, Rome http://www.fao.org/ forestry/20360-0381a9322cbc456bb05cfc9b6a7141cdf.pdf. Accessed 6 Sep 2020

Fick SE, Hijmans RJ (2017) WorldClim 2: new 1-km spatial resolution climate surfaces for global land areas. Int J Climatol 37(12):4302-4315. https://doi. org/10.1002/joc.5086

Frazier RJ, Coops NC, Wulder MA, Hermosilla T, White JC (2018) Analyzing spatial and temporal variability in short-term rates of post-fire vegetation return from Landsat time series. Remote Sens Environ 205:32-45. https://doi.org/10. 1016/j.rse.2017.11.007

Friis I, Demissew S, Breugel PV (2010) Atlas of the potential vegetation of Ethiopia. The Royal Danish Academy of Sciences and Letters https:// academic.oup.com/aob/article-lookup/doi/10.1093/aob/mcq242. Accessed 6 Sep 2020

Gazol A, Camarero JJ, Vicente-Serrano SM, Sánchez-Salguero R, Gutiérrez E, de Luis M, Sangüesa-Barreda G, Novak K, Rozas V, Tíscar PA, Linares JC, MartínHernández N, Martínez DCE, Ribas M, García-González I, Silla F, Camisón A, Génova M, Olano JM, Longares LA, Hevia A, Tomás-Burguera M, Galván JD (2018) Forest resilience to drought varies across biomes. Glob Chang Biol 24(5):2143-2158. https://doi.org/10.1111/gcb.14082

Gebrehiwot T, van der Veen A (2013) Climate change vulnerability in Ethiopia: disaggregation of Tigray region. J East Afr Stud 7(4):607-629. https://doi.org/ 10.1080/17531055.2013.817162

Gebru BM, Lee KW, Khamzina A, Wang WS, Cha S, Song C, Lamchin M (2020) Spatiotemporal multi-index analysis of desertification in dry afromontane forests of northern Ethiopia. Environ Develop Sust. https://doi.org/10.1007/s10668-020-00587-3

Giday K, Humnessa B, Muys B, Taheri F, Azadi H (2018) Effects of livestock grazing on key vegetation attributes of a remnant forest reserve: the case of Desa'a forest in northern Ethiopia. Global Ecol Conserv 14:e00395. https://doi.org/10. 1016/j.gecco.2018.e00395

Grimm V, Wissel C (1997) Babel, or the ecological stability discussions: an inventory and analysis of terminology and a guide for avoiding confusion. Oecologia 109(3):323-334. https://doi.org/10.1007/s004420050090

Guyot V, Castagneyrol B, Vialatte A, Deconchat M, Jactel H (2016) Tree diversity reduces pest damage in mature forests across Europe. Biology Letters 12(4): 0-4. https://doi.org/10.1098/rsbl.2015.1037

Gu H, Wang J, Ma L, Shang Z, Zhang Q (2019) Insights into the BRT (boosted regression trees) method in the study of the climate-growth relationship of Masson pine in subtropical China. Forests 10(3):1-20. https://doi.org/10.3390/ f10030228

Hillebrand H, Bennett DM, Cadotte MW (2008) Consequences of dominance: a review of evenness effects on local and regional ecosystem processes. Ecology 89(6):1510-1520

Hiltner U, Bräuning A, Gebrekirstos A, Huth A (2016) Impacts of precipitation variability on the dynamics of a dry tropical montane forest. Ecol Model 320(2016):92-101. https://doi.org/10.1016/j.ecolmodel.2015.09.021

Hird JN, DeLancey ER, McDermid GJ, Kariyeva J (2017) Google earth engine, open-access satellite data, and machine learning in support of large-area probabilisticwetland mapping. Remote Sens (Basel) 9(12). https://doi.org/10. 3390/rs9121315

Hishe H, Giday K, Van Orshoven J, Muys B, Taheri F, Azadi H, Feng L, Zamani O, Mirzaei M, Witlox F (2020) Analysis of land use land cover dynamics and driving factors in Desa'a forest in Northern Ethiopia. LAND USE POLICY. https://doi.org/10.1016/.llandusepol.2020.105039.

Huang J, Yu H, Guan X, Wang G, Guo R (2016) Accelerated dryland expansion under climate change. Nat Clim Chang 6(2):166-171. https://doi.org/10.1038/ nclimate2837

Hutchison C, Gravel D, Guichard F, Potvin C (2018) Effect of diversity on growth, mortality, and loss of resilience to extreme climate events in a tropical planted forest experiment. Sci Rep 8(1):1-10. https:/doi.org/10.1038/s41598-018-33670-x

Isbell FI, Polley HW, Wilsey BJ (2009) Biodiversity, productivity and the temporal stability of productivity: patterns and processes. Ecol Lett 12(5):443-451. https://doi.org/10.1111/j.1461-0248.2009.01299.x

Jacob M, Annys S, Frankl A, De Ridder M, Beeckman H, Guyassa E, Nyssen J (2014) Tree line dynamics in the tropical African highlands - identifying drivers and dynamics. J Veg Sci 26(1):9-20. https://doi.org/10.1111/jvs.12215
Jactel H, Menassieu P, Vetillard F, Gaulier A, Samalens JC, Brockerhoff EG (2006) Tree species diversity reduces the invasibility of maritime pine stands by the bast scale. Can J For Res 323:314-323. https://doi.org/10.1139/X05-251

Johnson KH, Kristiina AV, Heidi JC, Oswald JS, Daniel JV (1996) Biodiversity and the productivity and stability of ecosystems. Trends Ecol Evol 11(9):372-377. https://doi.org/10.1016/0169-5347(96)10040-9

Kogan FN (1995) Droughts of the late 1980s in the United States as derived from NOAA polar-orbiting satellite data. Bull Am Meteorol Soc 76(5):655-668. https://doi.org/10.1175/1520-0477(1995)076<0655:DOTLIT>2.0.CO;2

Leemput IA, Dakos V, Scheffer M, van Nes EH (2018) Slow recovery from local disturbances as an indicator for loss of ecosystem resilience. Ecosystems 21(1):141-152. https://doi.org/10.1007/s10021-017-0154-8

Lhermitte S, Verbesselt J, Verstraeten WW, Coppin P (2011) A comparison of time series similarity measures for classification and change detection of ecosystem dynamics. Remote Sens Environ 115(12):3129-3152. https://doi. org/10.1016/j.rse.2011.06.020

Lloret F, Lobo A, Estevan H, Maisongrande P, Vayreda J, Terradas J, Maisongrande P, Vayreda J (2007) Woody plant richness and NDVI response to drought events in Catalonian (northeastern Spain) forests. Ecology 88(9):2270-2279

Loreau M (2004) Does functional redundancy exist? Oikos 104(3):606-611. https:// doi.org/10.1111/j.0030-1299.2004.12685.x

Lu D, Chen Q, Wang G, Liu L, Li G, Moran E (2016) A survey of remote sensingbased aboveground biomass estimation methods in forest ecosystems. Int J Dig Earth 9(1):63-105. https://doi.org/10.1080/17538947.2014.990526

McCann K (2000) The diversity-stability debate. Nature 405(6783):228-233. https://doi.org/10.1038/35012234

Mokria M, Gebrekirstos A, Abiyu A, Van Noordwijk M, Bräuning A (2017) Multicentury tree-ring precipitation record reveals increasing frequency of extreme dry events in the upper Blue Nile River catchment. Glob Chang Biol. https://doi.org/10.1111/gcb.13809

Myers N, Mittermeier RA, Mittermeier CG, da Fonseca GAB, Kent J (2000) Biodiversity hotspots for conservation priorities. Nature 403(6772):853-858. https://doi.org/10.1038/35002501

Nikinmaa L, Lindner M, Cantarello E, Jump AS, Seidl R, Winkel G, Muys B (2020) Reviewing the use of resilience concepts in forest sciences. Curr Forest Report 6(2):61-80. https://doi.org/10.1007/s40725-020-00110-x

Nobre CA, Borma LDS (2009) "Tipping points" for the Amazon forest. Curr Opin Environ Sustain 1(1):28-36. https://doi.org/10.1016/j.cosust.2009.07.003

Nyssen J, Vandenreyken H, Poesen J, Moeyersons J, Deckers J, Haile M, Salles C, Govers G (2005) Rainfall erosivity and variability in the northern Ethiopian highlands. J Hydrol 311(1-4):172-187. https://doi.org/10.1016/j.jhydrol.2004. 12.016

O'Donnell MS, Ignizio DA (2012) Bioclimatic predictors for supporting ecological applications in the conterminous United States. U.S Geological Survey Data Series 691

Pimm SL (1984) The complexity and stability of ecosystems. Nature 37:321-326. https://doi.org/10.1038/307321a0

Quan J, Zhan W, Chen Y, Wang M, Wang J (2016) Time series decomposition of remotely sensed land surface temperature and investigation of trends and seasonal variations in surface urban heat islands. I Geophys Res Atm 175(121):2638-2657. https://doi.org/10.1002/2015JD024354

Ridgeway G (2007) Generalized boosted models: a guide to the gbm package. Computer 1(4):1-12. https://doi.org/10.1111/j.1467-9752.1996.tb00390.x

Rito KF, Arroyo-Rodríguez V, Queiroz RT, Leal IR, Tabarelli M (2017) Precipitation mediates the effect of human disturbance on the Brazilian Caatinga vegetation. J Ecol 105(3):828-838. https://doi.org/10.1111/1365-2745.12712

Safriel U, Adeel Z (2008) Development paths of drylands: thresholds and sustainability. Sustain Sci 3(1):117-123. https://doi.org/10.1007/s11625-0070038-5

Safriel U, Niemeijer D, Puigdefabregas J, White R, Lal R, Winslow M, Prince S, Archer E, King C, Shapiro B, Wessels K, Nielsen T, Portnov B, Reshef I, Lachman E, Mcnab D (2005) Dryland systems. In: Hassan R, Scholes R, Ash N (eds) Ecosystems and human well-being: current state and trends: findings of the condition and trends (the millennium ecosystem assessment series). Island Press, Washington: DC

Sánchez-Azofeifa GA, Quesada M, Rodríguez JP, Nassar JM, Stoner KE, Castillo A, Garvin T, Zent EL, Calvo-Alvarado JC, Kalacska MER, Fajardo L, Gamon JA, Cuevas-Reyes P (2005) Research priorities for neotropical dry forests. Biotropica 37(4):477-485. https://doi.org/10.1111/j.1744-7429.2005.00066.x

Schroth G, Laderach P, Dempewolf J, Philpott S, Haggar J, Eakin H, Castillejos T, Moreno JG, Pinto LS, Hernandez R, Eitzinger A, Ramirez-Villegas J (2009) 
Towards a climate change adaptation strategy for coffee communities and ecosystems in the Sierra Madre de Chiapas, Mexico. Mitig Adapt Strat Glob Chang 14(7):605-625. https://doi.org/10.1007/s11027-009-9186-5

Shannon CE (1948) A mathematical theory of communication. Bell Syst Tech J 27 : 379-423. https://doi.org/10.1145/584091.584093

Siyum ZG, Ayoade JO, Onilude MA, Feyissa MT (2019) Climate forcing of tree growth in dry Afromontane forest fragments of northern Ethiopia: evidence from multi-species responses. Forest Ecosyst 6:15. https://doi.org/10.1186/ s40663-019-0178-y

Sousa-Silva R, Verheyen K, Ponette Q, Bay E, Sioen G, Titeux H, Peer TV, Van Meerbeek K, Muys B (2018) Tree diversity mitigates defoliation after a drought-induced tipping point. Glob Chang Biol 24:4304-4315

Souza R, Feng X, Antonino A, Montenegro S, Souza E, Porporato A (2016) Vegetation response to rainfall seasonality and interannual variability in tropical dry forests. Hydrol Process 30(20):3583-3595. https://doi.org/10.1002/ hyp. 10953

Tefera AS, Ayoade JO, Bello NJ (2019) Drought occurrence pattern in Tigray Region, Northern Ethiopia. J Appl Sci Environ Manag 23(7):1341. https://doi. org/10.4314/jasem.v23i7.23

Tesemma AB (2007) Useful trees and shrubs of Ethiopia: identification, propagation, and management for 17 agroclimatic zones. RELMA in ICRAF Project, World Agroforestry Centre, Eastern Africa Region, Nairobi http:// books.google.com.et/books?id=15UfAQAAIAAJ. Accessed 6 Sep 2020

Tilman D, Reich PB, Knops JMH (2006) Biodiversity and ecosystem stability in a decade-long grassland experiment. Nature 441(7093):629-632. https://doi. org/10.1038/nature04742

Van Ruijven J, Berendse F (2007) Contrasting effects of diversity on the temporal stability of plant populations. Oikos 116:1323-1330. https://doi.org/10.1111/j. 2007.0030-1299.16005.x

Van Ruijven J, Berendse F (2010) Diversity enhances community recovery, but not resistance, after drought. J Ecol 98(1):81-86. https://doi.org/10.1111/j.13652745.2009.01603.x

Vannoppen A, Kint V, Ponette Q, Verheyen K, Muys B (2019) Tree species diversity impacts average radial growth of beech and oak trees in Belgium, not their long-term growth trend. Forest Ecosyst 6:10. https://doi.org/10.1186/s40663019-0169-z

Verbesselt J, Umlauf N, Hirota M, Holmgren M, Van Nes EH, Herold M, Zeileis A Scheffer M (2016) Remotely sensed resilience of tropical forests. Nat Clim Chang 6(11):1028-1031. https://doi.org/10.1038/nclimate3108

Waide RB, Willig MR, Steiner CF, Mittelbach G, Gough L, Dodson SI, Juday GP, Parmnter R (1999) The relationship between productivity and species richness. Annu Rev Ecol Evol Syst 30:257-300.

Wang J, Rich PM, Price KP, Kettle WD (2004) Relations between NDVI and tree productivity in the central Great Plains. Int J Remote Sens 25(16):3127-3138 https://doi.org/10.1080/0143116032000160499

Wang Y, Yu S, Wang J (2007) Biomass-dependent susceptibility to drought in experimental grassland communities. Ecol Lett 10(5):401-410. https:/doi.org/ $10.1111 / j .1461-0248.2007 .01031 . x$

Webb CT (2007) What is the role of ecology in understanding ecosystem resilience? BioScience 57(6). https://doi.org/10.1641/B570606

Williams FM (2016) Understanding Ethiopia. In: Bobrowsky PT, Burnaby BC, Martínez-Frías J (eds) Wolfgang Eder AV. Springer International Publishing, Australia. https://doi.org/10.1007/978-3-319-02180-5

Yan H, Zhan J, Zhang T (2011) The resilience of forest ecosystems and its influencing factors. Procedia Environ Sci 10:2201-2206. https://doi.org/10. 1016/j.proenv.2011.09.345

Yin $\mathrm{H}$, Udelhoven T, Fensholt R, Pflugmacher D, Hostert P (2012) How normalized difference vegetation index (NDVI) trends from advanced very high resolution radiometer (AVHRR) and système probatoire d'observation de la terre vegetation (SPOT VGT) time series differ in agricultural areas: an inner Mongolian case study. Remote Sens (Basel) 4(11):3364-3389. https://doi.org/ 10.3390/rs4113364

Zhang Z, Sheng L, Yang J, Chen XA, Kong L, Wagan B (2015) Effects of land use and slope gradient on soil erosion in a red soil hilly watershed of southern China. Sustainability 7(10):14309-14325. https://doi.org/10.3390/su71014309

\section{Submit your manuscript to a SpringerOpen ${ }^{\circ}$ journal and benefit from:}

- Convenient online submission

- Rigorous peer review

- Open access: articles freely available online

- High visibility within the field

- Retaining the copyright to your article

Submit your next manuscript at $\boldsymbol{\nabla}$ springeropen.com 